\title{
RECOMBINATION AND DIFFUSION PROCESSES IN ELECTRONIC GRADE 4H SILICON CARBIDE
}

\author{
P. Ščajev ${ }^{\text {a }}$ L. Subačius ${ }^{b}$, K. Jarašiūnas ${ }^{a}$, and M. Kato ${ }^{c, d}$ \\ ${ }^{a}$ Institute of Photonics and Nanotechnology, Vilnius University, Sauletekio 3, 10257 Vilnius, Lithuania \\ ${ }^{\mathrm{b}}$ Center for Physical Sciences and Technology, Sauletekio 3, 10257 Vilnius, Lithuania \\ ' Department of Engineering Physics, Electronics and Mechanics, Nagoya Institute of Technology, Nagoya 466-8555, Japan \\ ${ }^{\mathrm{d}}$ Frontier Research Institute for Materials Science, Nagoya Institute of Technology, Nagoya 466-8555, Japan \\ Email: liudvikas.subacius@ftmc.lt
}

Received 15 October 2018; revised 6 December 2018; accepted 2 January 2019

\begin{abstract}
Carrier dynamics in $n$-type $4 \mathrm{H}$-SiC epilayers of varying thicknesses and low $\mathrm{Z}_{1 / 2}$ defect concentrations are investigated here in wide ranges of excess carrier density and temperature. Several techniques are employed to monitor carrier diffusion and recombination processes, including light induced transient grating (LITG), microwave photoconductance decay (MPCD) and free carrier absorption (FCA) using ps-laser pulses at $355 \mathrm{~nm}$. The observed increase of the diffusion coefficient with the increasing excitation level is explained by the transition from the minority to the bipolar transport regime. Its subsequent decrease with even higher excitations is found to be governed by band-gap renormalization and degeneracy effects. The bulk lifetime, limited by hole traps at $0.19-0.24 \mathrm{eV}$ above the valence band at lower excitations, was found to decrease from few microseconds to hundreds of nanoseconds during the transition regime from the minority to the bipolar transport. Our temperature-dependent measurements confirmed the trap activation energy and provided the approximate functional form of electron and hole lifetimes as $\tau_{\mathrm{e}}=340 \times(T / 300 \mathrm{~K})^{3 / 2} \mathrm{~ns}$ and $\tau_{\mathrm{h}}=100 \times(T / 300 \mathrm{~K})^{-1 / 2} \mathrm{~ns}$, for the temperature $T$ range $80-800 \mathrm{~K}$. It was found to hold for 65 and $120 \mu \mathrm{m}$ sample thicknesses, while the lifetimes were found to be twice shorter for the sample $35 \mu \mathrm{m}$ thick.
\end{abstract}

Keywords: silicon carbide, microwave photoconductance, free carrier absorption, transient grating, lifetime

PACS: $72.20 . J v, 72.40 .+\mathrm{w}$

\section{Introduction}

Carrier lifetime is a crucial parameter for $4 \mathrm{H}-\mathrm{SiC}$ bipolar devices, thus many works are devoted to its investigation in epitaxial layers [1-7]. However, the injection level, temperature and defects lead to a wide variation of measured lifetimes. In $4 \mathrm{H}-\mathrm{SiC}$ $\mathrm{Z}_{1 / 2}$ traps are considered to be the main lifetime killing defects [1, 5], responsible for the increase of lifetime with excitation and temperature. Growth of $4 \mathrm{H}-\mathrm{SiC}$ at a high $\mathrm{C} / \mathrm{Si}$ ratio leads to a low $\mathrm{Z}_{1 / 2}$ density $\left(<10^{13} \mathrm{~cm}^{-3}\right)$ [5]; moreover, in such crystals lifetime decreases with excess carrier density, pointing out to recombination by other mechanisms. Lifetime decrease with nitrogen doping, not correlating with the $Z_{1 / 2}$ trap density, was also observed in [7]. The recombination mechanisms when intrinsic $Z_{1 / 2}$ trap density is negligibly low are often attributed to surface recombination, dislocations and stacking faults [8-11]. Few works also indicate that other point defects cannot be neglected [2, 12]. Hence, a combination of different techniques with a varying excitation density, sample thickness and temperature can provide a deeper insight into the recombination mechanisms and origin of the contributing defects. 
Therefore, we applied light induced transient grating (LITG), microwave photoconductance decay (MPCD) and free carrier absorption (FCA) techniques for study of the excitation and temperature-dependent carrier lifetime in 35, 65 and $120 \mu \mathrm{m}$ thick $4 \mathrm{H}-\mathrm{SiC}$ layers with a low $\mathrm{Z}_{1 / 2}$ defect concentration. The observed lifetime decrease with excitation and its increase with temperature were attributed to shallow hole traps at $E_{\mathrm{V}}+0.19-0.24 \mathrm{eV}$, the occupation of which with holes increases with excitation but decreases with temperature. The precise discrimination of bulk lifetime from surface and nonlinear recombination was performed by using a numerical simulation of the excess carrier density in-depth profile with the determined diffusion coefficient by LITG. The hole trap origin was ascribed to the HS1 hole trap attributable to silicon antisite $\mathrm{Si}_{6}$ with the position at $E_{\mathrm{V}}+210-240 \mathrm{meV}[2,13,14]$.

\section{Samples and techniques}

$4 \mathrm{H}-\mathrm{SiC}$ samples of 35,65 and $120 \mu \mathrm{m}$ thickness were produced [15] from a commercial $150 \mu \mathrm{m}$ thick $n$-type wafer $\left(n_{0}=(10 \pm 2) \times 10^{14} \mathrm{~cm}^{-3}\right.$ due to nitrogen doping) grown on a heavily-doped $4 \mathrm{H}$ $\mathrm{SiC}(0001)$ substrate at carbon rich conditions (C/ $\mathrm{Si} \approx 1.2)$. The latter feature led to a low $\mathrm{Z}_{1 / 2}$ density $\left(<5 \times 10^{12} \mathrm{~cm}^{-3}[16]\right)$ in the layers.

The investigated samples were excited by the third harmonic $(355 \mathrm{~nm})$ of a Nd:YAG laser with 25 ps duration pulses at $10 \mathrm{~Hz}$ repetition rate. Probing was performed by the first harmonic $(1064 \mathrm{~nm})$ of the Nd:YAG laser. The excitation fluence $I_{0}$ was tuned by rotating a half wave plate before a BBO Glan prism. The photoexcited carrier density at the surface is $\Delta N^{*}=\alpha I_{0} / h v$, where $\alpha$ is the temperature-dependent absorption coefficient of $4 \mathrm{H}-\mathrm{SiC}$ at $355 \mathrm{~nm}$ [17] (here $h v=3.49 \mathrm{eV}$ ). The statistically averaged carrier density $\Delta N(t)=\Delta N(z c, t)$ was used (where $z c$ was gerived from the condition $\left.\left.\int_{0}^{\mathrm{zc}} \Delta N(z, t) \mathrm{d} z=\int_{\mathrm{zc}}^{\mathrm{d}} \Delta N(z, t) \mathrm{d} z \quad 18\right]\right)$ for determination of instantaneous carrier lifetime excitation dependences.

LITG measurements were performed to determine the excitation-dependent diffusion coefficient $D$. In the measurements the interference light field is used to excite the sample [19-21]. LITG decay was monitored by diffraction of an optically delayed probe beam on a dynamic diffraction grating in the sample (due to the refractive index modulation $\Delta n$ by free carriers, $\Delta n(t) \sim \Delta N(t))$, thus leading to an instantaneous diffraction efficiency $\mathrm{DE}(t) \sim[\Delta N(t)]^{2}[20]$. Comparison of LITG decay times, $\tau_{\mathrm{G}}$, at few different grating periods $\Lambda$ allowed determination of the carrier diffusion coefficient $D$ and their fast lifetime component $\tau_{\mathrm{R}}$ as $1 / \tau_{\mathrm{G}}=1 / \tau_{\mathrm{R}}+4 \pi^{2} D / \Lambda^{2}$ [21]. Periods of 1.97 and $7.8 \mu \mathrm{m}$ were used for diffusivity determination.

MPCD measurements were utilized for investigation of carrier lifetime excitation dependences. In the MPCD measurements the sample was mounted into the rectangular waveguide setup and illuminated via a longitudinal slot of $2 \times 4 \mathrm{~mm}$ size by the Nd:YAG laser beam [22]. The illuminated surface area of the sample was $1.6 \times 1.6 \mathrm{~mm}$. Measurements based on the FCA technique provided carrier lifetimes at a high excess carrier density $\left(10^{16}-10^{18} \mathrm{~cm}^{-3}\right.$ range), at the same excitation conditions ( $355 \mathrm{~nm})$, and probing by the electronically delayed Nd:YAG laser (at $1064 \mathrm{~nm}$ ) [3]. Temperature-dependent lifetime measurements in the $80-800 \mathrm{~K}$ range were performed by the FCA technique in a nitrogen cooled cryostat.

\section{Results and discussion}

\subsection{Excitation-dependent carrier diffusivity from LITG}

At room temperature (RT) the excitation-dependent kinetics of LITG diffraction efficiency (DE) and the determined $D(\Delta N)$ dependence are shown in Fig. 1. The decay is becoming slower with excitation due to the decrease of the $D$ value, while the LITG signal amplitude increases quadratically with excitation as is typical for free carrier generation. We note that $D$ values at low excitations in $n$-type $4 \mathrm{H}$-SiC were determined by the Fourier transient grating (FTG) technique [23]. It has been observed that the $D$ increase with excitation (at $\Delta N<10^{16} \mathrm{~cm}^{-3}$ ) is due to transition from the monopolar hole to the bipolar diffusion regime [23], afterwards it decreases due to band-gap renormalisation (BGR) 24 and further slightly increases due to degeneracy [24]. 

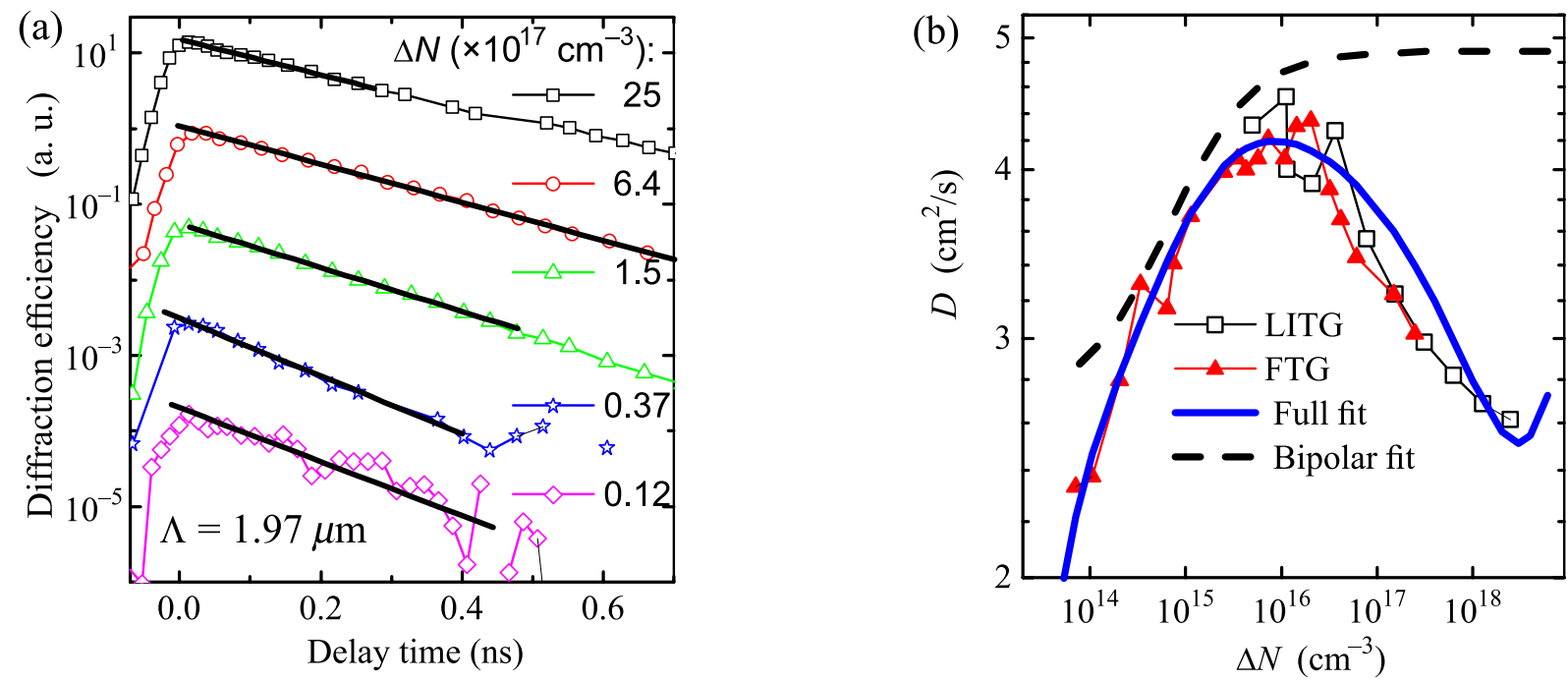

Fig. 1. The excitation-dependent DE decay (a) and diffusion coefficient (b). In (b) the upper dashed line shows the simulation without traps and BGR, while the lower solid line includes the impact of $1.5 \times 10^{13} \mathrm{~cm}^{-3} \mathrm{com}$ pensating boron traps, BGR, and degeneracy effects.

Electron-hole plasma is spatially inhomogeneous. Bipolar carrier diffusion is governed by the ambipolar diffusion coefficient [25] due to the internal electric field between electrons and holes

$$
D_{\mathrm{a} 0}(\Delta N)=\frac{n_{0}+2 \Delta N}{\left(n_{0}+\Delta N\right) / D_{\mathrm{h}}+(\Delta N) / D_{\mathrm{e}}},
$$

where $D_{\mathrm{e}}$ ir $D_{\mathrm{h}}$ are electron and hole diffusion coefficients, respectively. The diffusion coefficients $D$ are related to carrier mobilities $\mu$ via the Einstein's relationship [25]: $D=\mu k T / \mathrm{e}$. For $4 \mathrm{H}-\mathrm{SiC}$ $D_{\mathrm{h}}=2.7 \mathrm{~cm}^{2} / \mathrm{s}$ for holes and $D_{\mathrm{e}}=26 \mathrm{~cm}^{2} / \mathrm{s}$ for electrons $\left(\mu_{\mathrm{h}}=105 \mathrm{~cm}^{2} /(\mathrm{V} \cdot \mathrm{s}), \mu_{\mathrm{e}}=1000 \mathrm{~cm}^{2} /(\mathrm{V} \cdot \mathrm{s})[26]\right)$. The value $n_{0}=10^{15} \mathrm{~cm}^{-3}$ was used in the fit, presented in Fig. 1 (b) by the dashed line. It strongly deviates from the experimental data, thus pointing out to many body interactions at high excitations.

For a better comparison with the experiment, an analytical approximation to $D_{a}(\Delta N, T)$ was performed, taking into account the contributions of band-gap renormalization and plasma degeneracy [27], which can either reduce or enhance the diffusivity [24]:

$$
\begin{aligned}
& D_{\mathrm{a}}(T, \Delta N)=D_{\mathrm{a} 0}(\Delta N, T) \\
& \times\left[\left(1+a(T) \Delta N / 10^{18}\right)^{2 / 3}-b(T)\left(\Delta N / 10^{18}\right)^{1 / 3}\right] .
\end{aligned}
$$

Here $D_{\mathrm{a} 0}(T)$ is the low-injection, the phononlimited [24] diffusion coefficient, and the two terms in brackets represent plasma degeneracy and BGR, respectively. The $D_{\mathrm{a} 0}, a$ and $b$ are fitting parameters. $D_{\mathrm{a} 0}$ was used the same as in [24. The values of the parameters at RT were determined with $10 \%$ precision: $a=0.14, b=0.52$. The $a$ and $b$ coefficients were fitted with temperature as $a \propto T^{-1.5}$ and $b \propto T^{-1}$ (in degenerate plasma the density of states increases with temperature as $T^{1.5}$, while carriers with increased thermal energy $k T$ can more easily overcome the bandgap modulation due to BGR [27]). The low excitation value of diffusivity is not affected by many-body effects, thus should coincide with a bipolar one. However, in that case the observed lower $D$ value can be explained by fast carrier trapping to boron hole traps (negatively charged before excitation). According to the methodology given in [28], $D_{\text {meas }}=D_{\text {a } 0}\left(\Delta N-\Delta N_{\text {trapped }}\right) / \Delta N$, their density of $1.5 \times 10^{13} \mathrm{~cm}^{-3}$ was evaluated (see Fig. 1(b), full fit at $\left.\Delta N<10^{15} \mathrm{~cm}^{-3}\right)$. The determined $D(T, \Delta N)$ dependence will be used in carrier density profile simulations in Section 3.4.

\subsection{Excitation-dependent MPCD carrier lifetime}

The excitation-dependent MPCD kinetics in the $65 \mu \mathrm{m}$ thick sample are shown in Fig. 2(a). They become faster with excitation due to trap charging. The lifetime values determined in the respective intervals $\Delta t_{1}$ and $\Delta t_{2}$ are shown in Fig. 2(b). The clearly observed lifetime reduction indicates transition from a monopolar to a bipolar recombination case. Such dependence is untypical of $\mathrm{SiC}$ 

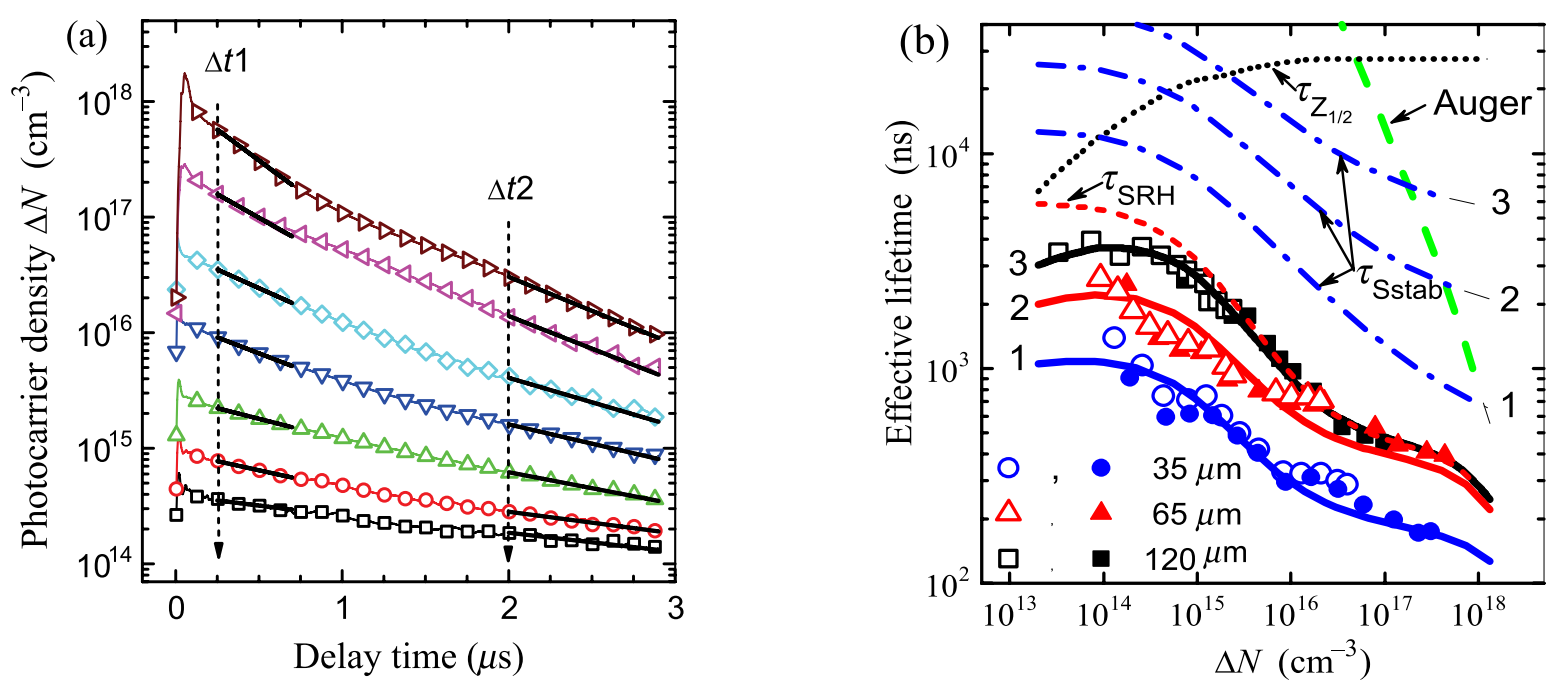

Fig. 2. (a) The time dependences of excess carrier density evaluated from the MPCD transients in the $65 \mu \mathrm{m}$ $4 \mathrm{H}-\mathrm{SiC}$ sample. Solid lines are the linear fit of the plots measured in small time intervals for different time delays, $\Delta t_{1}$ and $\Delta t_{2}$, as indicated in the graph. (b) The excitation-dependent effective carrier lifetime in the stabilised carrier profile decay for 35 (1), 65 (2) and 120 (3) $\mu \mathrm{m}$ samples. Dotted lines indicate the $Z_{1 / 2}$ defect impact, dash-dotted ones show the stabilized surface lifetime, dashed lines represent the Auger impact and short-dashed ones show the Shockley-Read-Hall lifetime. The fits at delay time $\Delta t_{1}$ (full plot symbols) and $\Delta t_{2}$ (open plot symbols) for the $35 \mu \mathrm{m}$ sample are 250 and $450 \mathrm{~ns}$, for the $65 \mu \mathrm{m}$ sample they are 250 and $2000 \mathrm{~ns}$, and for the $120 \mu \mathrm{m}$ sample the fits are 250 and $4500 \mathrm{~ns}$.

with a high concentration of vacancies, where lifetime decrease with excitation was observed [1]. Therefore the samples should contain other traps, the origin of which is unknown and needs further investigation.

Electronic traps are well known in $4 \mathrm{H}-\mathrm{SiC}$, thus we assume that hole traps are responsible for the observed recombination features. The model for the case when the defect concentration is much lower than the nonequilibrium carrier density, i.e. $\Delta N_{\mathrm{e}} \sim \Delta N_{\mathrm{h}} \sim \Delta N$, the Shockley-Read-Hall lifetime formula for hole traps (HT) can be derived [29]:

$$
\tau_{\mathrm{HT}}=\left(\tau_{\mathrm{h}}\left(n_{0}+\Delta N\right)+\tau_{\mathrm{e}}\left(p_{1 d}+\Delta N\right)\right) /\left(n_{0}+\Delta N\right) .
$$

Here $\tau_{\mathrm{e}}=1 /\left(N_{T} \sigma_{\mathrm{e}} v_{\text {th e }}\right), \tau_{\mathrm{h}}=1 /\left(N_{T} \sigma_{\mathrm{h}} v_{\text {th h }}\right), v_{\text {th }} \mathrm{e}=$ $\sqrt{8 / \pi k T / m_{\mathrm{e}}}$ and $v_{\text {th } \mathrm{h}}=\sqrt{8 / \pi k T / m_{\mathrm{h}}}{ }^{*}$ are the electron and hole lifetimes and thermal velocities; $\sigma_{\mathrm{e}}$ and $\sigma_{\mathrm{h}}$ are the capture cross sections for electrons and holes, and $n_{0}$ is the equilibrium electron concentration. $p_{1 d}=N_{v d} \exp \left(\left(E_{v}-E_{T}\right) / k T\right)$ is the hole concentration in the valence band when the Fermi level is equal to $E_{\mathrm{T}}$

Under high injection conditions for deep traps, Eq. (3) can be simplified to $\tau_{\mathrm{HT}}=\tau_{\mathrm{h}}+\tau_{\mathrm{e}}$, while for the minority carriers a simple form as $\tau_{\mathrm{HT}}=\tau_{\mathrm{h}}+\tau_{\mathrm{e}} p_{1 d} / n_{0}$ can be obtained.
The hole lifetime of $100 \mathrm{~ns}$ and the electron lifetime of 350 ns were determined using Eq. (3) in the thick layers, while for the thinner layer twice shorter lifetime values were fitted (see fits in Fig. 2(b)). The fitted hole trap energies are 210, 210 and $190 \mathrm{meV}$ in 35, 65 and $120 \mu \mathrm{m}$ samples, respectively. A low excitation lifetime is larger by $p_{1 d} / n_{0}$ ratio, therefore the hole lifetime in the thickest sample equals $350 \mathrm{~ns} \times 16=5.7 \mu$ s at low excitations. The shorter lifetime in the thinner layer will be checked by temperature measurements (Section 3.3). Herein we used hole trap lifetime discrimination from other lifetimes by the equation $1 / \tau_{\mathrm{R}}=1 / \tau_{\mathrm{HT}}+1 / \tau_{\mathrm{s}}+1 / \tau_{\mathrm{z}_{1 / 2}}+1 / \tau_{\text {Aug }}$, where the stabilised surface lifetime $\tau_{\mathrm{s}}$ was calculated from carrier density profiles (see Section 3.4), $1 / \tau_{Z_{1 / 2}}$ is the $Z_{1 / 2}$ defect limited lifetime calculated according to models in [1], and $\tau_{\text {Aug }}$ is the Auger lifetime calculated according to equations in detail described in [24].

\subsection{Temperature-dependent FCA carrier lifetime}

The transients of the FCA signal measured at $300 \mathrm{~K}$ are shown in Fig. 3(a). They are nonexponential and slower in thicker layers. It was observed that in thick samples decays at short delays are almost 

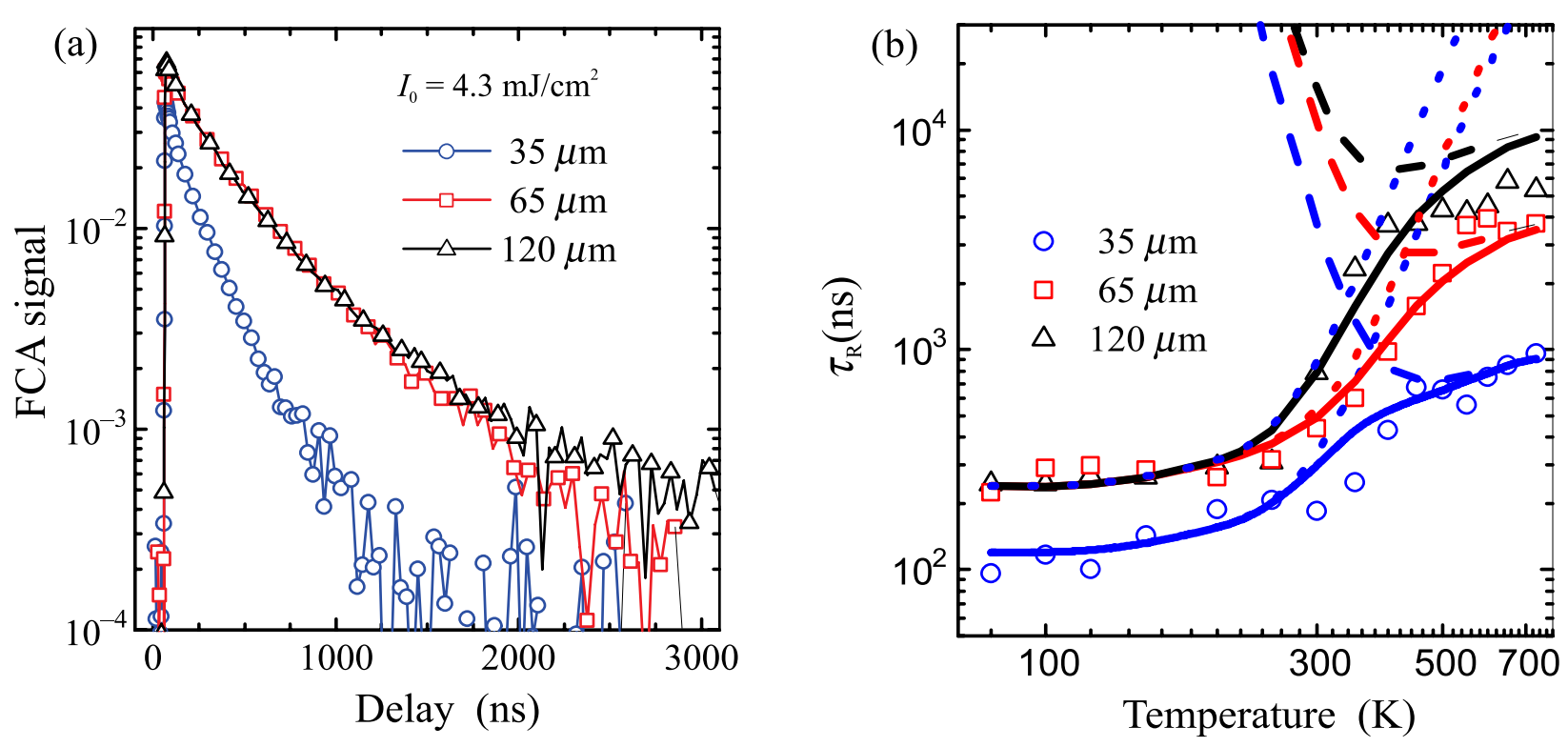

Fig. 3. FCA decays at $300 \mathrm{~K}$ measured for different sample thicknesses (a) and temperature-dependent lifetimes at $10^{16} \mathrm{~cm}^{-3}$ excess carrier density (b). In (b) solid lines are the total lifetime, dashed lines show the surface lifetime, and dotted ones are the bulk lifetime.

identical indicating that they are related mainly to bulk traps. Temperature lifetime measurements (Fig. 3(b)) were performed at $10^{16} \mathrm{~cm}^{-3}$ carrier density (as to minimize $\mathrm{Z}_{1 / 2}$ defect and Auger recombination impacts, see Fig. 2(b)) to verify hole trap activation energies and discriminate electron and hole lifetimes. All samples exhibited similar temperature dependences, pointing to a similar trap origin.

The fit of lifetime with temperature was performed by Eq. (3). It provided the temperature-dependent electron and hole lifetimes of $\tau_{\mathrm{e}}=340 \times(T / 300 \mathrm{~K})^{3 / 2} \mathrm{~ns}$ and $\tau_{\mathrm{h}}=100 \times(T / 300 \mathrm{~K})^{-1 / 2} \mathrm{~ns}$ in 65 and $120 \mu \mathrm{m}$ layers and twice shorter values in the thinnest one. The fitted hole trap activation energies were 220,240 and $190 \pm 20 \mathrm{meV}$ in 35,65 and $120 \mu \mathrm{m}$ samples, respectively. The latter values are very close to those determined from lifetime excitation dependences (see Fig. 3(b)). The hole lifetime decreased with temperature with a -0.5 slope which was explained by the hole capture to the neutral trap $\left(\sigma_{\mathrm{h}}=\right.$ const. [30] ) thus creating the $\mathrm{N}_{\mathrm{T}}{ }^{+}$state, while the electron lifetime increase with temperature with a 1.5 slope was explained by the electron capture to the positively charged hole trap state $\mathrm{N}_{\mathrm{T}}{ }^{+}\left(\sigma_{\mathrm{e}} \sim T^{2}\right.$, Coulombic trap [30]). The trap origin can be attributed to the HS1 silicon antisite $\mathrm{Si}_{\mathrm{C}}$ trap at the position $E_{\mathrm{V}}+210-240 \mathrm{meV}$ [2, 13]. The twice lower lifetime, observed in the $35 \mu \mathrm{m}$ sample, may indi- cate that defect density may increase with sample thickness decrease (our samples were thinned by polishing from the backside). Also the increase of trap energy with thickness may indicate a slight modification of the trap position on inequivalent hexagonal or cubic lattice sites. The effect is known to provide slightly different native defect energies in hexagonal $4 \mathrm{H}-\mathrm{SiC}$ [31]. Excitation from the backside in the thickest sample revealed the same lifetime value, as the carrier lifetime is integrated over the whole sample thickness.

\subsection{Carrier density profile simulations}

Straightforward determination of lifetime is possible when the carrier density in-depth profile is stabilized, i.e. from decay tails of the measured kinetics (the normalized stabilized carrier density in-depth profile and the corresponding stabilized surface lifetime are unchanged with time [3]). Therefore, the lifetime was extracted from decay tails in the used excitation and temperature ranges, as presented in Sections 3.2 and 3.3.

Below, we present the details on calculation of the spatial redistribution of carriers, governed by the carrier density and temperature-dependent diffusion and recombination. Using the balance equation (4) [32], we calculated the evolution of the excess carrier in-depth profile $\Delta N(z, t)$ in the epitaxial layer at standard boundary conditions $[33,34]$ : 


$$
\begin{aligned}
& \frac{\partial \Delta N(z, t)}{\partial t}=D_{\mathrm{a}}(T, \Delta N) \frac{\partial^{2} \Delta N(z, t)}{\partial z^{2}}-\frac{\Delta N(z, t)}{\tau_{\mathrm{SRH}}(T)} \\
& -C(T, \Delta N) \Delta N(z, t)^{3}+G(z, t) .
\end{aligned}
$$

Here $D_{\mathrm{a}}(T, \Delta N)$ and $C(T, \Delta N)$ are the temperature and injection dependent diffusion and the $\mathrm{Au}-$ ger recombination coefficient, respectively [24; $G(z, t)=\left[\alpha I_{\theta} f(t) / h v\right] \times \exp (-\alpha z)$ is the carrier generation rate by the laser pulse $f(t)[\beta]$. The solution of Eq. (4) is performed with the standard boundary conditions: $\Delta N(0 / d, t)= \pm \frac{D(\Delta N)}{S(\Delta N T)} \frac{\partial \Delta N(0 / d, t)}{\partial z}$, where $S(\Delta N, T)$ is the surface recombination velocity on front and back surfaces [33]. The dependence of the surface recombination velocity on the carrier density was determined by fitting the relation $S(\Delta N)=130 \times\left(1+2 \Delta N / n_{0}\right)^{1 / 2} \mathrm{~cm} / \mathrm{s}$, its theoretical description is provided in 22 The determined $S$ value was extracted from the initial parts of the MPCD and FCA decay with the relation $F C A(t)=\sigma_{\text {eh }} \int_{0}^{\mathrm{d}} \Delta N(z, t)$ $\times \mathrm{d} z$ [24], where $\sigma_{\text {eh }}$ is the free carrier absorption cross section. The stabilized surface recombination time was verified (with $10 \%$ error) by the equation $\tau_{\text {sstab }}=d / 2 S+(d / \pi)^{2} / D[3,33]$, where $S(T) \sim$ $\exp \left(-\phi_{\mathrm{B}} / k T\right)$ and $\phi_{\mathrm{B}}=\sim 260 \mathrm{meV}$ [18] is the surface defect capture barrier. Note that the normalized stabilized carrier density in-depth profile and lifetime are unchanged with time if $S$ and $D$ are constant on $\Delta N$.

An example of simulated profiles is shown in Fig. 4: in the thinner layer, the profile stabilization

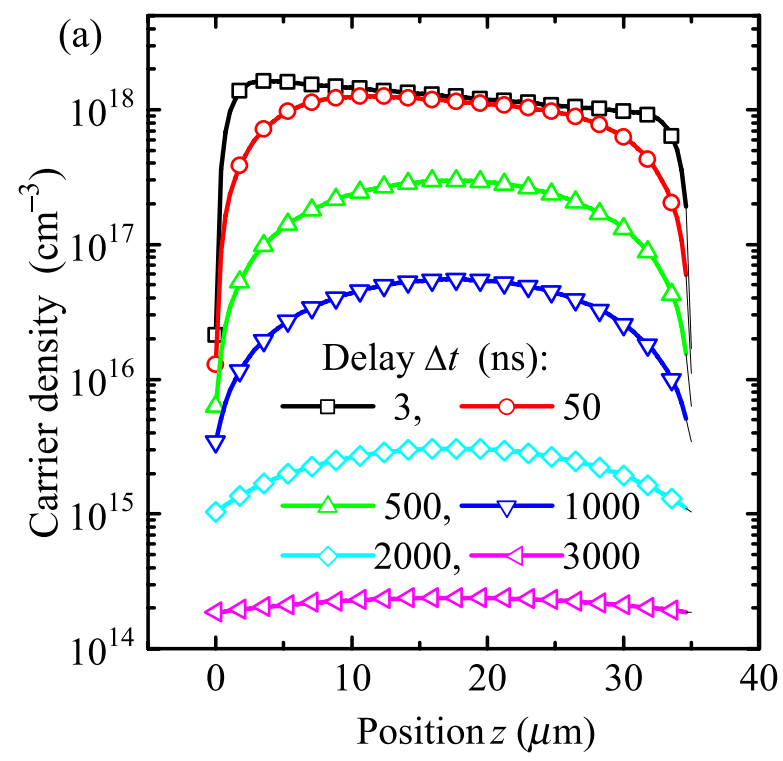

takes place in the few hundred nanosecond range, while in the thick ones it is in the microsecond range. The stabilized surface recombination time $\tau_{\text {Sstab }}$ excitation and temperature dependences are depicted in Figs. 2(b) and 3(b).

\section{Conclusions}

The light induced transient grating technique was applied for determination of the carrier diffusivity excitation dependence. The fitting of the measured excitation dependence exhibited monopolar and bipolar carrier transport regimes and the impact of many body effects studied in terms of bipolar plasma. The excitation-dependent lifetime was extracted from the MPCD transients in the 35, 65 and $120 \mu \mathrm{m}$ thick $4 \mathrm{H}-\mathrm{SiC}$ samples. The decrease of the carrier lifetime with the excitation provided hole trap energies in the $190-210 \mathrm{meV}$ range. The hole lifetime was $100 \mathrm{~ns}$ at $300 \mathrm{~K}$ in the thick layers, while that for the electrons was 350 ns. Increasing the FCA lifetime with temperature provided almost similar trap energies of 190 $240 \mathrm{meV}$. The determined hole trap was attributed to the HS1 silicon antisite hole trap. The hole lifetime decrease with temperature with a -0.5 slope was explained by the hole capture to the trap neutral state, while the electron lifetime increase with temperature with a 1.5 slope is due to the electron capture to the positively charged traps.

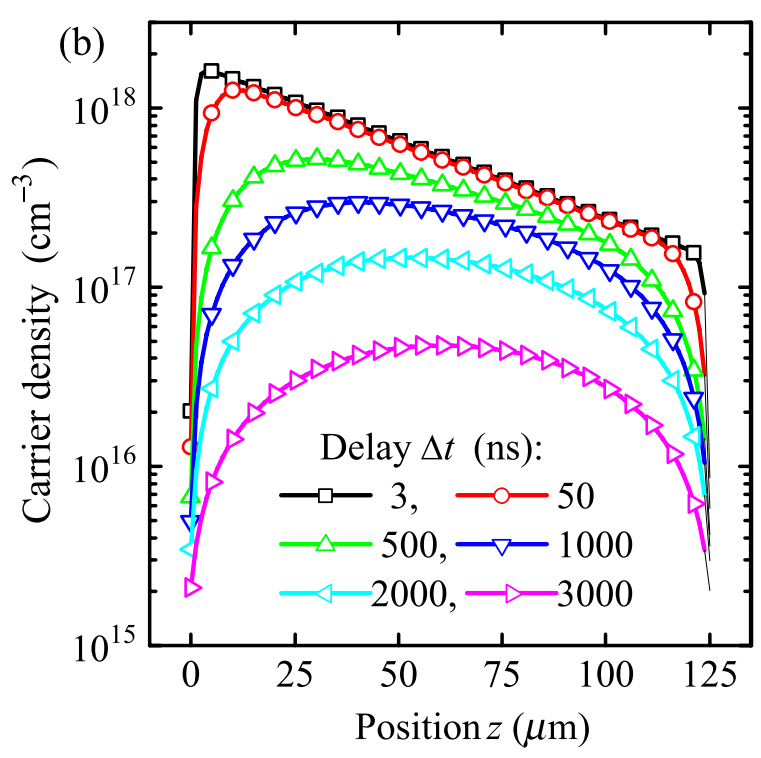

Fig. 4. Evolution of the spatial distribution of carrier density, calculated for thin (a) and thick (b) layers. Results are given for $I_{0}=5.6 \mathrm{~mJ} / \mathrm{cm}^{2}, \alpha=200 \mathrm{~cm}^{-1}$ and room temperature. 


\section{Acknowledgements}

We acknowledge collaborative links between the $\mathrm{Na}$ goya Institute of Technology and Vilnius University.

\section{References}

[1] P.B. Klein, Carrier lifetime measurement in $n^{-}$ 4H-SiC epilayers, J. Appl. Phys. 103(3), 033702 (2008), https://doi.org/10.1063/1.2837105

[2] P.B. Klein, A. Shrivastava, and T.S. Sudarshan, Slow de-trapping of minority holes in $n$-type $4 \mathrm{H}-\mathrm{SiC}$ epilayers, Phys. Stat. Solidi A 208(12), 2790-2795 (2011), https://doi.org/10.1002 pssa.201127260

[3] P. Ščajev, V. Gudelis, K. Jarašiūnas, and P.B. Klein, Fast and slow carrier recombination transients in highly excited $4 \mathrm{H}$ - and 3C-SiC crystals at room temperature, J. Appl. Phys. 108(2), 023705 (2010), https://doi.org/10.1063/1.3459894

[4] S. Ichikawa, K. Kawahara, J. Suda, and T. Kimoto, Carrier recombination in $n$-type $4 \mathrm{H}-\mathrm{SiC}$ epilayers with long carrier lifetimes, Appl. Phys. Express 5(10), 101301 (2012), https://doi.org/10.1143 APEX.5.101301

[5] T. Kimoto, K. Kawahara, B. Zippelius, E. Saito, and J. Suda, Control of carbon vacancy in SiC toward ultrahigh-voltage power devices, Superlatt. Microstruct. 99, 151-157 (2016), https://doi. org/10.1016/j.spmi.2016.03.029

[6] M. Kato, Y. Mori, and M. Ichimura, Microwave reflectivity from $4 \mathrm{H}-\mathrm{SiC}$ under a high-injection condition: impacts of electron-hole scattering, Jpn. J. Appl. Phys. 44(4S), 04DP14 (2015), https:// doi.org/10.7567/JJAP.54.04DP14

[7] R.L. Myers-Ward, B.L. VanMil, K.-K. Lew, P.B. Klein, E.R. Glaser, J.D. Caldwell, M.A. Mastro, L. Wang, P. Zhao, C.R. Eddy, Jr., and D.K. Gaskill, Investigation of deep levels in nitrogen doped $4 \mathrm{H}-\mathrm{SiC}$ epitaxial layers grown on $4^{\circ}$ and $8^{\circ}$ offaxis substrates, J. Appl. Phys. 108, 054906 (2010), https://doi.org/10.1063/1.3475152

[8] G. Feng, J. Suda, and T. Kimoto, Characterization of stacking faults in $4 \mathrm{H}-\mathrm{SiC}$ epilayers by roomtemperature microphotoluminescence mapping, Appl. Phys. Lett. 92(22), 221906 (2008), https:// doi.org/10.1063/1.2937097
[9] Y. Ishikawa, M. Sudo, Y.-Z. Yao, Y. Sugawara, and M. Kato, Expansion of a single Shockley stacking fault in a $4 \mathrm{H}-\mathrm{SiC}$ (1120) epitaxial layer caused by electron beam irradiation, J. Appl. Phys. 123(22), 225101 (2018), https://doi.org/10.1063/1.5026448

[10]P. Ščajev, J. Hassan, K. Jarašiūnas, M. Kato, A. Henry, and J.P. Bergman, Comparative studies of carrier dynamics in 3C-SiC layers grown on $\mathrm{Si}$ and $4 \mathrm{H}-\mathrm{SiC}$ substrates, J. Electron. Mater. 40(4), 394-399 (2011), https://doi.org/10.1007/s11664010-1378-y

[11]B. Chen, H. Matsuhata, T. Sekiguchi, A. Kinoshita, K. Ichinoseki, and H. Okumura, Tuning minority-carrier lifetime through stacking fault defects: The case of polytypic SiC, Appl. Phys. Lett. 100(13), 132108 (2012), https://doi. org/10.1063/1.3700963

[12]J. Zhang, L. Storasta, J.P. Bergman, N.T. Son, and E. Janzen, Electrically active defects in $n$-type $4 \mathrm{H}$-silicon carbide grown in a vertical hot-wall reactor, J. Appl. Phys. 93, 4708 (2003), https://doi. org/10.1063/1.1543240

[13]L. Torpo, M. Marlo, T.E.M. Staab, and R.M. Nieminen, Comprehensive $a b$ initio study of properties of monovacancies and antisites in $4 \mathrm{H}-\mathrm{SiC}$, J.Phys. Condens.Matter 13(28),6203-6231(2001), https://doi.org/10.1088/0953-8984/13/28/305

[14]L. Storasta, J.P. Bergman, E. Janzen, A. Henry, and J. Lu, Deep levels created by low energy electron irradiation in 4H-SiC, J. Appl. Phys. 96(9), 4909 (2004), https://doi.org/10.1063/1.1778819

[15]Y. Ichikawa, M. Ichimura, T. Kimoto, and M. Kato, Passivation of surface recombination at the $\mathrm{Si}$ face of $4 \mathrm{H}-\mathrm{SiC}$ by acidic solutions, ECS J. Solid State Sci. Technol. 7(8), Q127-Q130 (2018), https://doi.org/10.1149/2.0031808jss

[16]T. Kimoto, K. Danno, and J. Suda, Lifetimekilling defects in $4 \mathrm{H}-\mathrm{SiC}$ epilayers and lifetime control by low-energy electron irradiation, Phys. Stat. Solidi B 245(7), 1327-1336 (2008), https:// doi.org/10.1002/pssb.200844076

[17]P. Ščajev, M. Kato, and K. Jarašiūnas, A diffraction-based technique for determination of interband absorption coefficients in bulk 3C-, $4 \mathrm{H}$ - and 6H-SiC crystals, J. Phys. D 44(36), 365402 (2011), https://doi.org/10.1088/0022-3727/44/36/365402 
[18]P.B. Klein, R. Myers-Ward, K.-K. Lew, B.L. VanMil, C.R. Eddy, D.K. Gaskill Jr., A. Shrivastava, and T.S. Sudarshan, Recombination processes controlling the carrier lifetime in $n^{-} 4 \mathrm{H}$-SiC epilayers with low $\mathrm{Z}_{1 / 2}$ concentrations, J. Appl. Phys. 108, 033713 (2010),https://doi.org/10.1063/1.3466745

[19]H.J. Eichler, P. Gunter, and D.W. Pohl, Laserinduced Dynamic Grattings (Springer-Verlag, New York, 1986).

[20]K. Jarasiunas, R. Aleksiejunas, T. Malinauskas, V. Gudelis, T. Tamulevicius, S. Tamulevicius, A. Guobiene, A. Usikov, V. Dmitriev, and H.J. Gerritsen, Implementation of diffractive optical element in four-wave mixing scheme for ex situ characterization of hydride vapor phase epitaxygrown GaN layers, Rev. Sci. Instrum. 78(3), 33901 (2007), https://doi.org/10.1063/1.2712788

[21]P. Ščajev, R. Aleksiejūnas, S. Miasojedovas, S. Nargelas, M. Inoue, C. Qin, T. Matsushima, C. Adachi, and S. Juršènas, Two regimes of carrier diffusion in vapor-deposited lead-halide perovskites, J. Phys. Chem. C 121(39), 21600-21609 (2017), https://doi.org/10.1021/acs.jpcc.7b04179

[22]L. Subačius, K. Jarašiūnas, P. Ščajev, and M. Kato, Development of a microwave photoconductance measurement technique for the study of carrier dynamics in highly-excited $4 \mathrm{H}-\mathrm{SiC}$, Meas. Sci. Technol. 26(12), 125014 (2015), https://doi. org/10.1088/0957-0233/26/12/125014

[23]P. Grivickas, J. Linnros, and V. Grivickas, Carrier diffusion characterization in epitaxial $4 \mathrm{H}-\mathrm{SiC}$, J. Mater. Res. 16(2), 524-528 (2001), https://doi. org/10.1557/JMR.2001.0075

[24]P. Ščajev and K. Jarašiūnas, Temperature- and excitation-dependent carrier diffusivity and recombination rate in $4 \mathrm{H}-\mathrm{SiC}$, J. Phys. D 46(26), 265304 (2013), https://doi.org/10.1088/0022$3727 / 46 / 26 / 265304$

[25]J. Linnros and V. Grivickas, Carrier-diffusion measurements in silicon with a Fouriertransient-grating method, Phys. Rev. B 50, 16943-16955 (1994), https://doi.org/10.1103 PhysRevB.50.16943
[26]J. Pernot, S. Contreras, and J. Camassel, Electrical transport properties of aluminum-implanted 4H-SiC, J. Appl. Phys. 98, 023706 (2005), https:// doi.org/10.1063/1.1978987

[27]J.F. Young and H.M. Driel, Ambipolar diffusion of high-density electrons and holes in Ge, Si, and GaAs: Many-body effects, Phys. Rev. B 26, 2147-2158 (1982), https://doi.org/10.1103/ PhysRevB.26.2147

[28]G. Liaugaudas, P. Ščajev, and K. Jarašiūnas, Carrier dynamics and photoelectrical parameters in highly compensated sublimation grown 3C-SiC layers studied by time-resolved nonlinear optical techniques, Semicond. Sci. Technol. 29(1), 015004 (2014), https://doi.org/10.1088/02681242/29/1/015004

[29]W. Shockley and W.T. Read, Statistics of the recombinations of holes and electrons, Phys. Rev. 87, 835-842 (1952).

[30]B.K. Ridley, Quantum Processes in Semiconductors (Clarendon Press, Oxford, 1999).

[31]N.T. Son, X.T. Trinh, L.S. Løvlie, B.G. Svensson, K. Kawahara, J. Suda, T. Kimoto, T. Umeda, J. Isoya, T. Makino, T. Ohshima, and E. Janzén, Negative- $U$ system of carbon vacancy in $4 \mathrm{H}-\mathrm{SiC}$, Phys. Rev. Lett. 109, 187603 (2012), https://doi. org/10.1103/PhysRevLett.109.187603

[32]M. Boulou and D. Bois, Cathodoluminescence measurements of the minority-carrier lifetime in semiconductors, J. Appl. Phys. 48(11), 4713-4721 (1977), https://doi.org/10.1063/1.323537

[33]A.B. Sproul, Dimensionless solution of the equation describing the effect of surface recombination on carrier decay in semiconductors, J. Appl. Phys. 76, 2851-2854 (1994), https://doi. org/10.1063/1.357521

[34] S.S. Suvanam, K. Gulbinas, M. Usman, M.K. Linnarson, D.M. Martin, J. Linnros, V. Grivickas, and A. Hallén, 4H-silicon carbide-dielectric interface recombination analysis using free carrier absorption, J. Appl. Phys. 117, 105309 (2015), https:// doi.org/10.1063/1.4914521 


\title{
REKOMBINACIJOS IR DIFUZIJOS PROCESAI ELEKTRONINĖS KOKYBĖS 4H SILICIO KARBIDE
}

\author{
P. Ščajev ${ }^{a}$, L. Subačius ${ }^{b}$, K. Jarašiūnas ${ }^{a}$, M. Kato ${ }^{c}$ \\ ${ }^{a}$ Vilniaus universiteto Fotonikos ir nanotechnologiju institutas, Vilnius, Lietuva \\ ${ }^{\mathrm{b}}$ Fiziniu ir technologijos moksly centras, Vilnius, Lietuva \\ ${ }^{\mathrm{c}}$ Nagojos technologijos institutas, Nagoja, Japonija
}

\begin{abstract}
Santrauka
Darbe tiriama krūvininkų dinamika jų tankio $10^{14}-10^{18} \mathrm{~cm}^{-3}$ ir temperatūros $80-800 \mathrm{~K}$ intervaluose fotosužadintuose $n$-tipo $4 \mathrm{H}$-SiC sluoksniuose, 35,65 ir $120 \mu \mathrm{m}$ storio, legiruotuose $10^{15} \mathrm{~cm}^{-3}$ tankio azoto priemaišomis bei turinčiuose mažą $\mathrm{Z}_{1 / 2}$ defektų tankị. Śviesa indukuotų dinaminių gardelių, mikrobangų fotolaidumo bei laisvụjų krūvininkų sugerties metodikos buvo pritaikytos krūvininkų rekombinacijos ir difuzijos vyksmų tyrimams, naudojant sužadinimui pikosekundinio Nd:YAG lazerio impulsus, esant $355 \mathrm{~nm}$ bangos ilgiui. Krūvininkų difuzijos koeficiento didejimas, nustatytas intensyvinant žadinimą, buvo paaiškintas pernašos mechanizmų kaita, monopolio transporto
\end{abstract}

virsmu bipoliu. Stipraus žadinimo atveju gautas difuzijos koeficiento sumažejimas buvo priskirtas daugiadalelei sąveikai bipoleje plazmoje: energijos juostų renormalizacijai ir išsigimimui. Be to, intensyvinant žadinimą, buvo nustatyta, kad trumpèja krūvininkų gyvavimo trukmè (nuo kelių mikrosekundžių iki šimtų nanosekundžių). Trumpėjimas buvo paaiškintas skylių gaudyklių (lygmuo ties $E_{\mathrm{V}}+0.19-0.24 \mathrm{eV}$ ) ittaka bei bipolès pernašos mechanizmų fotosužadintame $4 \mathrm{H}$ $\mathrm{SiC}$ kaita. Atlikti temperatūriniai laisvųjų krūvininkų sugerties tyrimai patvirtino mūsų modeliniuose skaičiavimuose panaudotą gaudyklių aktyvacijos energijos vertę bei leido nustatyti elektronų ir skylių gyvavimo trukmių temperatūrines priklausomybes. 